\title{
Effects of increasing amounts of corn dried distillers grains with solubles in dairy cow diets on methane production, ruminal fermentation, digestion, $\mathbf{N}$ balance, and milk production
}

\author{
C. Benchaar, ${ }^{* 1}$ F. Hassanat, ${ }^{*}$ R. Gervais, † P. Y. Chouinard,† C. Julien,ł H. V. Petit, ${ }^{*}$ and D. I. Massé ${ }^{*}$ \\ ${ }^{*}$ Agriculture and Agri-Food Canada, Dairy and Swine Research and Development Centre, 2000 College Street, Sherbrooke, Quebec, \\ Canada J1M 0C8 \\ †Université Laval, Département des Sciences Animales, Québec, Québec, Canada G1V 0A6 \\ fUMR INRA-INPT ENSAT-INPT ENVT 1289 Tissus Animaux Nutrition Digestion Ecosystème et Métabolisme, F-31326 Castanet Tolosan, France
}

\section{ABSTRACT}

The objective of this study was to examine the effects of including corn dried distillers grains with solubles (DDGS) in the diet at the expense of corn and soybean meal on enteric $\mathrm{CH}_{4}$ emissions, ruminal fermentation characteristics, digestion (in sacco and apparent totaltract digestibility), $\mathrm{N}$ balance, and milk production of dairy cows. Twelve lactating Holstein cows were used in a triplicated $4 \times 4$ Latin square design $(35-\mathrm{d}$ periods) and fed (ad libitum intake) a total mixed ration containing (dry matter basis) 0, 10, 20, or $30 \%$ DDGS. Dry matter intake increased linearly, whereas apparent-total tract digestibility of dry matter and gross energy declined linearly as DDGS level in the diet increased. Increasing the proportion of DDGS in the diet decreased the acetate:propionate ratio, but this decrease was the result of reduced acetate concentration rather than increased propionate concentration. Milk yield increased linearly (up to $+4 \mathrm{~kg} / \mathrm{d}$ ) with increasing levels of DDGS in the diet and a tendency was observed for a quadratic increase in energy-corrected milk as the proportion of DDGS in the diet increased. Methane production decreased linearly with increasing levels of DDGS in the diet $(495,490,477$, and 475 $\mathrm{g} / \mathrm{d}$ for $0,10,20$, and 30\% DDGS diets, respectively). When adjusted for gross energy intake, $\mathrm{CH}_{4}$ losses also decreased linearly as DDGS proportion increased in the diet by 5,8 , and $14 \%$ for 10,20 , and $30 \%$ DDGS diets, respectively. Similar decreases (up to $12 \%$ at $30 \%$ DDGS) were also observed when $\mathrm{CH}_{4}$ production was corrected for digestible energy intake. When expressed relative to energy-corrected milk, $\mathrm{CH}_{4}$ production declined linearly as the amount of DDGS increased in the diet. Total $\mathrm{N}$ excretion (urinary and fecal; g/d) increased as the amount of DDGS in the diet increased.

Received August 6, 2012.

Accepted December 27, 2012.

${ }^{1}$ Corresponding author: chaouki.benchaar@agr.gc.ca
Efficiency of $\mathrm{N}$ utilization (milk $\mathrm{N}$ secretion as a proportion of $\mathrm{N}$ intake) declined linearly with increasing inclusion of DDGS in the diet. However, productive N increased linearly with increasing proportions of DDGS in the diet, suggesting better efficiency of $\mathrm{N}$ use by the animal. Results from this study show that feeding DDGS to dairy cows can help to mitigate enteric $\mathrm{CH}_{4}$ emissions without negatively affecting intake and milk production.

Key words: corn distillers grains with solubles, methane, dairy cow

\section{INTRODUCTION}

Methane is a significant component of greenhouse gases, playing a key role in global warming. Enteric fermentation is a major source of on-farm $\mathrm{CH}_{4}$ emissions, contributing up to $34 \%$ (86 million t/yr) of all agricultural emissions, and could rise up to $48 \%$ (114 million t/yr) in 2020 (EPA, 2006; FAO, 2006). Several studies have reported that increasing fat content in ruminant diets can reduce enteric $\mathrm{CH}_{4}$ production. This has been reported with lipids from vegetable oils (McGinn et al., 2004; Beauchemin et al., 2007; Martin et al., 2008) and oilseeds (Beauchemin et al., 2009; Grainger et al., 2010; Chung et al., 2011). However, vegetable oils and oilseeds are expensive ingredients and the advantage of lowering enteric $\mathrm{CH}_{4}$ emissions could be counterbalanced by a loss of profit when such mitigation strategy is applied at the farm level.

Recent growth of the ethanol industry in North America has resulted in increased availability of byproducts, most commonly dried distillers grains with solubles (DDGS). Corn DDGS contain 11 to $17 \%$ ether extract (Getachew et al., 2004; Penner et al., 2009; Schingoethe et al., 2009) and, therefore, DDGS can be used as a fat supplement to reduce enteric $\mathrm{CH}_{4}$ emissions from dairy cows. Moreover, DDGS contain, on average, $30 \% \mathrm{CP}$ of which $55 \%$ are ruminally undegradable (Janicek et al., 2008) and, thus, it can represent an interesting source of protein for dairy cow nutrition. Only a few studies 
have evaluated the potential of using DDGS to reduce enteric $\mathrm{CH}_{4}$ production from ruminants. Birkelo et al. (2004) replaced corn and soybean meal with wet corn distillers grains ( $31 \%$ of dietary DM) in early lactation dairy cow diets and reported a $14 \%$ decline in $\mathrm{CH}_{4}$ energy losses [as a proportion of gross energy (GE) intake) with no concomitant effect on milk yield. More recently, McGinn et al. (2009) reported a $24 \%$ decrease in $\mathrm{CH}_{4}$ energy losses (percentage of $\mathrm{GE}$ intake) and improved feed efficiency (gain:feed ratio) in beef cattle when DDGS replaced barley grain in the diet. To our knowledge, the effect of including DDGS in the TMR of dairy cows on enteric $\mathrm{CH}_{4}$ production has not been studied yet. Moreover, no information is available on the optimal amount of DDGS to feed to mitigate enteric $\mathrm{CH}_{4}$ emissions without adversely affecting dairy cow performance. The purpose of this study was to examine the effects of including increasing amounts of DDGS $(0,10,20$, and 30\%; DM basis) in the diet at the expense of corn and soybean meal on enteric $\mathrm{CH}_{4}$ production, rumen fermentation, digestion, $\mathrm{N}$ balance, milk production, and milk composition of dairy cows.

\section{MATERIALS AND METHODS}

This study was conducted at the Dairy and Swine Research and Development Centre (Sherbrooke, Quebec, Canada). Animal procedures were conducted under the approval of the Institutional Animal Care Committee of the Dairy and Swine Research and Development Centre and were in accordance with the guidelines of the Canadian Council on Animal Care (Ottawa, ON, Canada; CCAC, 1993).

\section{Cows, Experimental Design, and Diets}

Twelve multiparous (2.6 \pm 0.67 parity) lactating Holstein cows fitted with rumen cannulas $(10 \mathrm{~cm}$; Bar Diamond Inc., Parma, ID) were used in a in triplicated $4 \times 4$ Latin square design (35-d periods). The cows averaged $99 \pm 18$ DIM at the start of the experiment, with an average BW of $645 \pm 49 \mathrm{~kg}$ and production of $40 \pm 4 \mathrm{~kg}$ of milk/d. During the experiment, cows were housed in individual tiestalls, and allowed free access to water. Cows were fed for ad libitum intake $(5 \%$ orts, on an as-fed basis) 1 of the 4 following dietary treatments: (1) 0\% DDGS, (2) 10\% DDGS, (3) 20\% DDGS, and (4) $30 \%$ DDGS, on a DM basis (Table 1). The DDGS replaced flaked corn (i.e., source of energy) and soybean meal (i.e., source of protein) in the diets, which were formulated to be isonitrogenous (i.e., similar dietary CP concentration) and isocaloric (i.e., similar $\mathrm{NE}_{\mathrm{L}}$ concentration). Dried distillers grains with solubles (a single batch) were obtained from GreenField Ethanol Inc.
(Varennes, QC). After 2 wk (i.e., 14 d) of adaptation to experimental diets, feed intake, apparent total-tract digestibility, $\mathrm{N}$ balance, milk production, milk composition (i.e., $7 \mathrm{~d}$ ), in sacco ruminal degradability (i.e., $5 \mathrm{~d}$ ), rumen fermentation characteristics (i.e., $2 \mathrm{~d}$ ), and $\mathrm{CH}_{4}$ production (i.e., 3 d) were measured. Only 2 air-flow controlled chambers were available for measuring $\mathrm{CH}_{4}$ emissions in this study, which limited the number of animals that could be examined at the same time to 2 (i.e., 1 cow per chamber). Consequently, the groups of cows had to be staggered by $4 \mathrm{~d}$ to facilitate measurements. Cows were weighed at the beginning and the end of each experimental period on 2 consecutive days before the a.m. feeding and after the a.m. milking.

\section{Feed Intake, Apparent Total-Tract Digestibility, and N Balance}

Apparent total-tract digestibility and $\mathrm{N}$ outputs were measured over 7 consecutive days. Diets were offered in equal amounts twice daily (0900 and $1930 \mathrm{~h}$ ). Feed consumption was recorded daily by weighing feeds offered to and refused by the cows. Samples of the TMR, feed ingredients, and orts were collected daily and stored at $-20^{\circ} \mathrm{C}$. Samples were composited by cow within period, freeze dried, ground to pass a 1-mm screen using a Wiley mill (standard model 4; Arthur M. Thomas Co., Philadelphia, PA) and analyzed for DM, OM, total N, NDF, ADF, starch, ether extract (EE), and GE.

Total collection of feces and urine was performed by fitting cows with harnesses and tubes allowing the collection of feces and urine separately. Feces were weighed and mixed daily, and a representative sample $(2 \%)$ was collected, stored at $-20^{\circ} \mathrm{C}$, and subsequently thawed, freeze dried, and ground to pass a 1-mm screen using a Wiley mill for later analysis of $\mathrm{OM}$, total N, NDF, ADF, starch, ether extract, and GE. Total urine was collected daily into reinforced plastic containers containing an appropriate amount of $\mathrm{H}_{2} \mathrm{SO}_{4}(50 \% \mathrm{vol} / \mathrm{vol})$ to maintain $\mathrm{pH}<2.0$. A representative sample $(2 \%)$ was collected and kept frozen at $-20^{\circ} \mathrm{C}$ until analyzed for total $\mathrm{N}$. Retained $\mathrm{N}$ was calculated by subtracting $\mathrm{N}$ in feces, urine, and milk from $\mathrm{N}$ intake. Productive $\mathrm{N}$ was calculated as the sum of $\mathrm{N}$ retained in the body and $\mathrm{N}$ secreted in milk.

\section{In Sacco Ruminal Degradability}

Ruminal degradability of timothy hay (i.e., source of fiber), soybean meal (i.e., source of protein), and flaked corn (i.e., source of starch) was determined on 1 Latin square (4 cows) using a nylon bag procedure. Feeds were ground to pass a 1-mm screen using a Wiley mill and 5-g samples (DM basis) were weighed in duplicate 
Table 1. Ingredient composition (DM basis) of the experimental diets containing increasing amounts of corn dried distillers grains with solubles (DDGS)

\begin{tabular}{lrrrr}
\hline & \multicolumn{4}{c}{ DDGS } \\
\cline { 2 - 5 } Ingredient (\%) & \multicolumn{1}{c}{$0 \%$} & $10 \%$ & $20 \%$ & $30 \%$ \\
\hline Alfalfa silage & 22.9 & 22.9 & 22.9 & 22.9 \\
Corn silage & 33.8 & 33.8 & 33.8 & 33.8 \\
Timothy hay & 3.4 & 3.4 & 3.4 & 3.4 \\
Flaked corn & 16.7 & 11.0 & 5.7 & 0.0 \\
Soybean meal & 13.2 & 8.8 & 4.4 & 0.0 \\
DDGS & 0.0 & 10.1 & 19.9 & 30.0 \\
Beet pulp, dehydrated & 7.6 & 7.6 & 7.5 & 7.5 \\
Calcium carbonate & 0.7 & 0.7 & 0.8 & 0.8 \\
Mineral and vitamin supplement ${ }^{1}$ & 1.6 & 1.6 & 1.5 & 1.5
\end{tabular}

${ }^{1}$ Contained $12.48 \% \mathrm{Ca}, 6.80 \% \mathrm{P}, 6.81 \% \mathrm{~S}, 7.72 \% \mathrm{Na}, 1.97 \% \mathrm{~K}, 96 \mathrm{mg}$ of I $/ \mathrm{kg}, 2,877 \mathrm{mg}$ of Fe $/ \mathrm{kg}, 620 \mathrm{mg}$ of $\mathrm{Cu} / \mathrm{kg}, 2,520 \mathrm{mg}$ of $\mathrm{Mn} / \mathrm{kg}, 3,777 \mathrm{mg}$ of $\mathrm{Zn} / \mathrm{kg}, 83 \mathrm{mg}$ of $\mathrm{Co} / \mathrm{kg}, 628,000 \mathrm{IU}$ of vitamin $\mathrm{A} / \mathrm{kg}, 81,000 \mathrm{IU}$ of vitamin $\mathrm{D} / \mathrm{kg}, 3,739 \mathrm{IU}$ of vitamin $\mathrm{E} / \mathrm{kg}$, and $27.8 \mathrm{mg}$ of $\mathrm{Se} / \mathrm{kg}$.

in polyester bags $(17 \times 9 \mathrm{~cm} ; 53-\mu \mathrm{m}$ pore size $)$ made of monofilament PeCap polyester (Sefar Nitex; Sefar AG, Heiden, Switzerland). Bags were placed in a large mesh $(46 \times 38 \mathrm{~cm} ; 3 \times 5$-mm pores) retaining sac containing a $700 \mathrm{~g}$ anchor to keep the bags immersed in the rumen while allowing the rumen fluid to circulate freely. Bags were soaked in $37^{\circ} \mathrm{C}$ water for 5 min before being placed in the ventral sac of the rumen for $2,4,8,16$, 24,48 , and $72 \mathrm{~h}$ for soybean meal and flaked corn and $2,4,8,16,24,48,72$, and $96 \mathrm{~h}$ for hay. Upon removal from the rumen, bags were immediately immersed in ice water to impede microbial activity and then thoroughly rinsed with cold tap water and frozen at $-20^{\circ} \mathrm{C}$. Bags were later thawed, washed in a domestic washing machine, and dried for $48 \mathrm{~h}$ at $55^{\circ} \mathrm{C}$. Bags and contents were weighed and dried residues were ground through a 1-mm screen (1093 Cyclotec Sample Mill; Foss Tecator AB, Höganäs, Sweden) and stored for subsequent determination of DM and OM. Bags used for time 0 disappearance were soaked in water at $37^{\circ} \mathrm{C}$ for $5 \mathrm{~min}$, and then treated similar to the other bags.

Kinetics of ruminal degradation of OM of hay, soybean meal and flaked corn was calculated using a nonlinear model (McDonald, 1981). The PROC NLIN of SAS (SAS Institute Inc., Cary, NC) was used to fit the following model:

$$
\begin{gathered}
\mathrm{P}=\mathrm{a}+\mathrm{b}\left(1-\mathrm{e}^{-\mathrm{c}(t-\mathrm{L})}\right) \text { for } t>\mathrm{L} ; \\
\mathrm{P}=\mathrm{a} \text { for } t \leq \mathrm{L},
\end{gathered}
$$

where $\mathrm{P}=$ percentage of $\mathrm{OM}$ disappearance from the nylon bag at time $t, \mathrm{a}=$ soluble and rapidly degradable fraction $(\%), \mathrm{b}=$ slowly degradable fraction $(\%), \mathrm{c}=$ fractional rate of disappearance of the fraction $b(/ h)$, $\mathrm{L}=$ lag time (h), and $t=$ time of incubation (h). The model was fitted using $(a+b) \leq 100, b \geq 0, c \geq 0$, and $\mathrm{L} \geq 0$ constraints.
The effective ruminal degradability (ERD) of OM was calculated using the following equation:

$$
\mathrm{ERD}=\mathrm{a}+[\mathrm{bc} /(\mathrm{c}+\mathrm{kp})] \times \mathrm{e}^{(-\mathrm{kpL})},
$$

where $\mathrm{kp}$ is the ruminal fractional passage rate, calculated at $0.05 / \mathrm{h}$ for timothy hay and $0.061 / \mathrm{h}$ for soybean meal and flaked corn, from the equations suggested by the NRC (2001) for dry forages and concentrates.

\section{Ruminal Fermentation Characteristics and Protozoa Enumeration}

Ruminal fluid was collected from cows on 2 successive days before $(0 \mathrm{~h})$ and at $1,2,4,6$, and $8 \mathrm{~h}$ after the a.m. feeding. A total of $250 \mathrm{~mL}$ was collected from the anterior dorsal, anterior ventral, medium ventral, posterior dorsal, and posterior ventral locations within the rumen using a $50-\mathrm{mL}$ syringe screwed to a stainless tube ending with a probe covered by a fine metal mesh (RT rumen fluid collection tube; Bar Diamond Inc.). Ruminal fluid $\mathrm{pH}$ was measured immediately after sampling (Accumet pH meter; Fisher Scientific, Montreal, QC, Canada), and samples were acidified to $\mathrm{pH} 2$ with $50 \% \mathrm{H}_{2} \mathrm{SO}_{4}$ and frozen at $-20^{\circ} \mathrm{C}$ for later determination of VFA and ammonia $\left(\mathrm{NH}_{3}\right)$ concentrations.

Protozoa enumeration was carried out on rumen content collected $4 \mathrm{~h}$ after the a.m. feeding on 2 consecutive days. Ruminal content $(1 \mathrm{~L})$ was strained through 4 layers of cheesecloth and a 5 -mL portion of the strained rumen fluid was preserved using $5 \mathrm{~mL}$ of methyl green formalin-saline solution for protozoa enumeration (Ogimoto and Imai, 1981). Protozoa samples were stored at room temperature in darkness until counting. Protozoa were microscopically enumerated using a counting chamber (Neubauer Improved Bright-Line counting cell, 0.1-mm depth; Hausser Scientific Co., Horsham, PA). Each sample was counted twice, and if the average 
of the duplicates differed by more than $10 \%$, the counts were repeated.

\section{Milk Production and Milk Composition}

Cows were milked twice daily at 0700 and $1900 \mathrm{~h}$ in their stalls and milk production was recorded at each milking. During digestibility measurements (i.e., 7 d), milk samples were collected from each cow at each milking, stored at $+4^{\circ} \mathrm{C}$ with a preservative (2-bromo2-nitropropan-1,3-diol), and then sent to a commercial laboratory (Valacta Laboratories, Sainte-Anne-de-Bellevue, QC, Canada) for analyses of fat, protein, lactose, MUN, and SCC.

\section{Methane Production Measurement}

Two air-flow controlled chambers were used for measurement of $\mathrm{CH}_{4}$ production. The chambers measured $4.09 \mathrm{~m}$ length $\times 2.95 \mathrm{~m}$ width $\times 2.84 \mathrm{~m}$ height. When chambers doors were closed, air entered the chamber through a ventilation duct and exited through an exhaust. Air temperature within the chamber was maintained at $18 \pm 1^{\circ} \mathrm{C}$. Air flow into and out of the chamber was measured using inline mass flowmeters (FT2; Fox Thermal Instruments Inc., Marina, CA) and maintained at $180 \pm 10 \mathrm{~m}^{3} / \mathrm{h}$. Methane concentration was continuously measured at the air entrance and exhaust ducts using $\mathrm{CH}_{4}$ analyzers (MGA3000; ADC Gas Analysis Ltd., Hoddesdon, Hertfordshire, UK). The amount of $\mathrm{CH}_{4}$ (entering and leaving the chamber) was calculated by multiplying the concentration of $\mathrm{CH}_{4}$ by the airflow (at entrance and at exhaust). The difference between the incoming and outgoing mass of $\mathrm{CH}_{4}$ corresponded to the amount of enteric $\mathrm{CH}_{4}$ emitted in each chamber by the animal. The chambers were calibrated before the experiment by releasing known amounts of $\mathrm{CH}_{4}$ in each chamber (with no cow inside) and calculating the recovered amounts from the difference incoming and ingoing $\mathrm{CH}_{4}$. The recovered amounts ranged from 98 to $102 \%$. The calibration factors (i.e., to adjust each chamber to $100 \%$ recovery) were used to correct $\mathrm{CH}_{4}$ emissions data. A small positive pressure was generated inside each chamber to prevent inflow of gases into the chambers. Cows were preconditioned to the environmental chambers before the beginning of the experiment. To reduce the effect of isolation on animal behavior, the chambers were equipped with windows and speakers so the cow in the chamber can see and hear other cows. Cows entered the chambers $18 \mathrm{~h}$ before starting $\mathrm{CH}_{4}$ measurements. Methane was recorded every minute over a period of 3 consecutive days and fluxes were averaged to derive 24-h $\mathrm{CH}_{4}$ emissions. Within each chamber, the cow was kept in a tiestall that measured $1.82 \mathrm{~m}$ long $\times 1.60 \mathrm{~m}$ wide, elevated from the floor by $25 \mathrm{~cm}$. Manure was collected from each cow in a stainless box placed below and to the rear of each stall. Farm personnel accessed the chambers twice daily (0800 and $2000 \mathrm{~h}$ ) to feed and milk the cows and remove the manure. The doors were kept opened for a maximum of 1 to 1.5 min to allow exchange of material in and out of the chambers. This resulted in interruptions of flux measurements for 15 to $30 \mathrm{~min}$, which is the time required for gas concentrations to reach steady state. These interruptions had a little effect on daily emissions because fluxes were calculated every minute and used to derive the 24 -h period emissions values. Cows in the chambers had free access to water and were fed twice daily for ad libitum intake $(5 \%$ orts on an as-fed basis). Offered feed and orts were weighed daily to determine feed consumption. Samples of feed offered and orts were collected, pooled, and kept frozen for later determination of DM and GE concentrations.

\section{Chemical Analyses}

Dry matter was determined by oven drying at $55^{\circ} \mathrm{C}$ for $48 \mathrm{~h}$. Analytical DM was determined by drying in a vacuum oven at $100^{\circ} \mathrm{C}$ overnight (AOAC, 1990; method 934.01). Ash content was determined by incineration at $550^{\circ} \mathrm{C}$ overnight in a muffle furnace (AOAC, 1990; method 942.05) and the OM content was calculated as the difference between 100 and the percentage of ash. Crude protein $(\mathrm{N} \times 6.25)$ was determined using the macro-Kjeldahl procedure (AOAC, 1990; method 990.03). The concentration of NDF was determined as described by Van Soest et al. (1991) without the use of sodium sulfite and with the inclusion of heat-stable $\alpha$-amylase. The ADF content was determined according to AOAC (1990; method 973.18). The NDF and ADF procedures were adapted for use in an Ankom200 fiber analyzer (Ankom Technology Corp., Fairport, NY). The concentration of starch was determined colorimetrically according to the procedure of Hall (2001). Ether extract was determined using the Soxtec 2047 SoxCap in combination with Soxtec extraction systems (Foss, Eden Prairie, MN) according to the AOAC (1990; method 920.39). Gross energy was determined using an oxygen bomb calorimeter (model 6200; Parr Instrument Co., Moline, IL). The concentration of $\mathrm{N}$ in acidified urine samples was determined by microKjeldahl analysis (AOAC, 1990).

Ruminal VFA concentration was determined using HPLC Agilent Technologies 1200 Series (Agilent Technologies Canada Inc., Mississauga, ON, Canada). The HPLC was equipped with an RI detector and Aminex HPX-87H column $(300 \times 7.8 \mathrm{~mm})$ packed with sulfonated divinyl benzene-styrene copolymer (Bio-Rad 
Laboratories Ltd., Mississauga, ON, Canada). The mobile phase was $0.005 M$ sulfuric acid and the flow rate was $0.6 \mathrm{~mL} / \mathrm{min}$. Ammonia $\mathrm{N}$ concentration in ruminal fluid was determined as in Weatherburn (1967). Protein, fat, lactose, urea $\mathrm{N}$, and SCC in milk samples were analyzed by infrared spectroscopy (MilkoScan FT 6000; Foss Electric A/S, Hillerød, Denmark). Milk composition was corrected for differences in milk yield between a.m. and p.m. milkings.

\section{Statistical Analyses}

Data were analyzed using PROC MIXED of SAS (SAS Institute Inc.). The statistical model included treatment and period as fixed effects and square and cows within square as random effects. Ruminal fermentation characteristics $\left(\mathrm{pH}, \mathrm{VFA}\right.$, and $\left.\mathrm{NH}_{3}\right)$ data were analyzed as repeated measures using the same model with the addition of the fixed effects of day, sampling time (i.e., h) and all interactions. The $\mathrm{CH}_{4}$ and protozoa data were also analyzed as repeated measures with the inclusion of the fixed effects of day and day $\times$ treatment interaction. For $\mathrm{CH}_{4}$ data, the fixed effect of the chamber was initially included in the model but was removed because it was not significant. In sacco ruminal degradability data were analyzed as a $4 \times 4$ Latin square design and the model included the fixed effects of treatment and period, and the random effect of cow. Orthogonal polynomial contrasts (linear and quadratic) were used to examine treatment effect on response variables. Significant effect of treatment on least squares means was declared when $P \leq 0.05$, whereas tendencies were declared when $0.05<P \leq 0.10$.

\section{RESULTS AND DISCUSSION}

\section{Diet Composition}

Ingredients of the experimental diets are shown in Table 1, whereas the chemical composition of the experimental diets, DDGS, flaked corn, and soybean meal are presented in Table 2. The DDGS used in our study contained slightly less CP (27.9 vs. $31.1 \pm 1.54 \%$; mean $\pm \mathrm{SD}$ ), more $\mathrm{EE}(16.3$ vs. $11.9 \pm 2.12 \%$; mean $\pm \mathrm{SD}$ ), and similar NDF concentrations (32.1 vs. 32.7 $\pm 2.93 \%$; mean $\pm \mathrm{SD}$ ) compared with previous studies (Anderson et al., 2006; Kleinschmit et al., 2007; Janicek et al., 2008; McGinn et al., 2009; Ranathunga et al., 2010). In the current study, DDGS $(0,10,20$, and $30 \%$ of dietary DM) replaced flaked corn $(16.7,11.0$, 5.7 , and $0 \%$ of dietary DM) and soybean meal (13.2, $8.8,4.4$, and $0 \%$ of dietary DM) and, consequently, as the DDGS proportion in the diet increased, EE and fiber (NDF and ADF) concentrations of the dietary treatments increased, whereas the starch content decreased (Table 2). Even though diets were formulated to be isocaloric and isonitrogenous, increasing DDGS in the diet resulted in a slight increase in GE and $\mathrm{CP}$ concentrations.

\section{Intake and Apparent Total-Tract Digestibility}

Intake of DM increased linearly $(P<0.01)$ as dietary DDGS proportion increased in the diet (Table 3 ). Cows offered diets with the highest DDGS proportion consumed 8\% more DM than cows fed 0\% DDGS diet. Intake of $\mathrm{OM}, \mathrm{GE}, \mathrm{CP}, \mathrm{NDF}$, and EE increased linearly $(P<0.01)$ with increasing DDGS proportions in the diet, whereas starch intake declined linearly $(P<0.01)$. The effects of feeding DDGS on feed intake have been variable among studies. Similarly to our observations, Nichols et al. (1998) replaced soybean meal and corn with DDGS (20\% of dietary DM) and observed greater DMI for cows fed DDGS diet than for cows fed a control diet. More recently, Janicek et al. (2008) reported a linear increase in DMI for cows fed diets containing increasing amounts of DDGS (up to $30 \%$; DM basis) included at the expense of forage and concentrate ingredients. Kleinschmit et al. (2006) reported no difference

Table 2. Chemical composition of the diets, corn dried distillers grains with solubles (DDGS), soybean meal, and flaked corn

\begin{tabular}{|c|c|c|c|c|c|c|c|}
\hline \multirow[b]{2}{*}{ Item } & \multicolumn{4}{|c|}{ DDGS } & \multicolumn{3}{|c|}{ Ingredient } \\
\hline & $0 \%$ & $10 \%$ & $20 \%$ & $30 \%$ & DDGS & $\begin{array}{c}\text { Flaked } \\
\text { corn }\end{array}$ & $\begin{array}{c}\text { Soybean } \\
\text { meal }\end{array}$ \\
\hline $\mathrm{OM}(\%$ of $\mathrm{DM})$ & 93.0 & 92.9 & 92.6 & 92.5 & 95.2 & 98.3 & 92.7 \\
\hline $\mathrm{CP}(\%$ of $\mathrm{DM})$ & 16.2 & 16.4 & 16.6 & 16.8 & 27.9 & 8.35 & 51.5 \\
\hline $\mathrm{NDF}(\%$ of DM) & 32.3 & 33.8 & 36.3 & 37.8 & 32.1 & 8.69 & 8.47 \\
\hline $\mathrm{ADF}(\%$ of $\mathrm{DM})$ & 21.8 & 21.8 & 22.9 & 23.3 & 13.2 & 2.78 & 6.28 \\
\hline Starch $(\%$ of DM $)$ & 19.0 & 15.8 & 13.7 & 11.2 & 2.20 & 64.0 & 1.12 \\
\hline Ether extract (\% of DM) & 3.99 & 4.98 & 6.06 & 7.16 & 16.3 & 6.29 & 3.77 \\
\hline Gross energy (Mcal $/ \mathrm{kg}$ of DM) & 4.46 & 4.54 & 4.63 & 4.73 & 5.41 & 4.44 & 4.65 \\
\hline $\mathrm{NE}_{\mathrm{L}}^{1}$ (Mcal/kg of DM) & 1.62 & 1.63 & 1.65 & 1.66 & 2.29 & 2.09 & 2.13 \\
\hline
\end{tabular}

${ }^{1}$ Calculated according to NRC (2001). 
in DMI when DDGS ( $\mathrm{CP}=30.5 \%, \mathrm{NDF}=47.8 \%$, and $\mathrm{EE}=10.6 \%$ ) replaced corn and soybean meal in dairy cow diets (20\% of the dietary DM). Contrary to our findings, Birkelo et al. (2004) reported an 11\% decline in DMI when wet corn distillers grains $(\mathrm{CP}=39.5 \%$, $\mathrm{NDF}=58.1 \%$, and $\mathrm{EE}=8.5 \%$ ) were included (at $31 \%$ of dietary DM) in dairy cow diets at the expense of corn and soybean meal, whereas Anderson et al. (2006) reported a tendency $(P=0.09)$ for lower DMI for cows fed $20 \%$ of wet or dry corn distillers grains (replacing corn and soybean meal) diets compared with cows fed the control diet. Discrepancies between studies in DMI response to feeding corn distillers grains could be related to differences in experimental conditions, such as the rate of inclusion of corn distillers grains with solubles, the type of feed ingredient of the basal diet (forage or concentrate, or both) being replaced by the distillers grains, and the form (wet or dry) of this byproduct to feed. Kleinschmit et al. (2007) showed that ruminal degradability and intestinal digestibility differed widely among DDGS sources, reflecting a great variation in the quality (i.e., chemical composition) of DDGS, which may further explain the variable DMI between studies.

Dry matter and OM and GE digestibility of the diet declined linearly $(P<0.01)$ with increasing DDGS proportions in the diet. Digestibility of ADF averaged $60.5 \%$ and was not affected $(P \geq 0.80)$ by DGGS addition to the diet. Digestibility of NDF slightly increased when DDGS was supplied up to $20 \%$ of dietary DM and then declined at $30 \%$ of DDGS supplementation level, causing a quadratic $(P=0.05)$ effect of treatment. Apparent total-tract digestibility of $\mathrm{CP}(P=0.02)$ and EE $(P<0.01)$ increased linearly, whereas starch digestibility increased quadratically $(P<0.01)$ as the proportion of DDGS in the diet increased. Zhang et al. (2010) replaced concentrates (rolled barley and canola meal) in dairy cow diets with $20 \%$ dried distillers grains and solubles from corn and wheat. They observed a numerically higher DMI for cows fed DDGS diets, and reported a significant decrease in apparent total-tract digestibility of DM and an increase in that of NDF and EE, which agrees with our findings observed with a 20\% DDGS diet. Birkelo et al. (2004) also reported a numerical decline in DM digestibility coupled with an increase in $\mathrm{CP}$ and EE digestibility when $31.2 \%$ wet distillers grains replaced soybean meal and corn in dairy cow diets, which also corroborates findings of the present study.

Several studies reported a decline in diet digestibility when dietary fat level increased (Beauchemin et al., 2007; Chung et al., 2011), which explains the effect of DDGS addition on DM, OM, energy, and NDF (at $30 \%$ DDGS) digestibility observed in the current study. The increase in NDF digestibility when DDGS were included up to $20 \%$ of dietary DM reflects the high degradability of NDF from DDGS. In vitro NDF digestibility of DDGS is high, ranging from 68 to $73 \%$ (Getachew et al., 2004; Robinson et al., 2008; Tedeschi et al., 2009). It has been reported that corn distillers grain-based diets reduce chewing activity (Penner et al., 2009; Zhang et al., 2010), and thus may increase ruminal passage rate (Janicek et al., 2008), which may also explain the effect of DDGS on DMI and digestibility observed in the present study. Although DMI tended to increase, eating, rumination, and total chew-

Table 3. Intake and apparent total-tract digestibility of nutrients in lactating cows fed diets supplemented with increasing amounts of corn dried distillers grains with solubles (DDGS)

\begin{tabular}{|c|c|c|c|c|c|c|c|}
\hline \multirow[b]{2}{*}{ Item } & \multicolumn{4}{|c|}{ DDGS } & \multirow[b]{2}{*}{ SEM } & \multicolumn{2}{|c|}{$P$-value } \\
\hline & $0 \%$ & $10 \%$ & $20 \%$ & $30 \%$ & & Linear & Quadratic \\
\hline \multicolumn{8}{|l|}{ Intake } \\
\hline $\mathrm{DM}(\mathrm{kg} / \mathrm{d})$ & 23.4 & 24.4 & 24.8 & 25.2 & 0.63 & $<0.01$ & 0.45 \\
\hline $\mathrm{OM}(\mathrm{kg} / \mathrm{d})$ & 21.7 & 22.7 & 22.9 & 23.3 & 0.58 & $<0.01$ & 0.44 \\
\hline GE (Mcal/d) & 104 & 111 & 115 & 119 & 2.9 & $<0.01$ & 0.54 \\
\hline $\mathrm{NDF}(\mathrm{kg} / \mathrm{d})$ & 7.50 & 8.23 & 9.00 & 9.53 & 0.239 & $<0.01$ & 0.54 \\
\hline $\mathrm{ADF}(\mathrm{kg} / \mathrm{d})$ & 5.06 & 5.30 & 5.65 & 5.87 & 0.153 & $<0.01$ & 0.90 \\
\hline $\mathrm{CP}(\mathrm{kg} / \mathrm{d})$ & 3.79 & 4.02 & 4.09 & 4.26 & 0.110 & $<0.01$ & 0.71 \\
\hline $\operatorname{Starch}(\mathrm{kg} / \mathrm{d})$ & 4.31 & 3.87 & 3.40 & 2.83 & 0.119 & $<0.01$ & 0.57 \\
\hline $\mathrm{EE}^{1}(\mathrm{~kg} / \mathrm{d})$ & 0.93 & 1.21 & 1.50 & 1.81 & 0.038 & $<0.01$ & 0.62 \\
\hline \multicolumn{8}{|l|}{ Digestibility (\%) } \\
\hline $\mathrm{DM}$ & 70.7 & 70.2 & 69.6 & 68.1 & 0.63 & $<0.01$ & 0.12 \\
\hline $\mathrm{OM}$ & 72.5 & 71.9 & 71.1 & 69.8 & 0.60 & $<0.01$ & 0.28 \\
\hline GE & 69.6 & 69.2 & 68.7 & 67.6 & 0.51 & $<0.01$ & 0.32 \\
\hline $\mathrm{NDF}$ & 56.0 & 56.9 & 57.4 & 54.8 & 1.11 & 0.42 & 0.05 \\
\hline $\mathrm{ADF}$ & 60.6 & 60.4 & 60.3 & 60.6 & 1.35 & 0.98 & 0.80 \\
\hline $\mathrm{CP}$ & 67.3 & 68.3 & 68.4 & 69.2 & 0.70 & 0.03 & 0.80 \\
\hline Starch & 94.7 & 95.4 & 96.2 & 98.8 & 0.30 & $<0.01$ & $<0.01$ \\
\hline $\mathrm{EE}$ & 53.0 & 53.8 & 57.4 & 59.4 & 1.84 & $<0.01$ & 0.73 \\
\hline
\end{tabular}

${ }^{1} \mathrm{EE}=$ ether extract. 
Table 4. In sacco OM degradation kinetic parameters and effective degradability of flaked corn, soybean meal, and timothy hay incubated in the rumen of lactating cows fed diets supplemented with increasing amounts of corn dried distillers grains with solubles (DDGS)

\begin{tabular}{|c|c|c|c|c|c|c|c|}
\hline \multirow[b]{2}{*}{ Item $^{1}$} & \multicolumn{4}{|c|}{ DDGS } & \multirow[b]{2}{*}{ SEM } & \multicolumn{2}{|c|}{$P$-value } \\
\hline & $0 \%$ & $10 \%$ & $20 \%$ & $30 \%$ & & Linear & Quadratic \\
\hline \multicolumn{8}{|l|}{ Corn, flaked } \\
\hline $\mathrm{b}(\%)$ & $\begin{array}{l}43.2 \\
56.2\end{array}$ & 56.2 & 54.9 & 56.3 & 0.51 & $\begin{array}{l}0.41 \\
0.61\end{array}$ & $\begin{array}{l}0.61 \\
0.19\end{array}$ \\
\hline $\mathrm{c}(/ \mathrm{h})$ & 0.055 & 0.059 & 0.060 & 0.061 & 0.0052 & 0.32 & 0.71 \\
\hline Lag time $(\mathrm{h})$ & 0.00 & 0.00 & 0.00 & 0.04 & 0.020 & 0.23 & 0.36 \\
\hline $\operatorname{ERD}(\%)$ & 69.4 & 70.4 & 70.5 & 71.4 & 1.21 & 0.13 & 0.94 \\
\hline \multicolumn{8}{|l|}{ Soybean meal } \\
\hline $\mathrm{a}(\%)$ & 40.2 & 40.2 & 40.3 & 40.4 & 0.06 & 0.06 & 0.78 \\
\hline b (\%) & 59.6 & 59.7 & 59.4 & 59.5 & 0.19 & 0.52 & 0.88 \\
\hline$c(/ h)$ & 0.126 & 0.104 & 0.085 & 0.086 & 0.0170 & 0.08 & 0.48 \\
\hline Lag time $(\mathrm{h})$ & 0.96 & 0.85 & 0.32 & 0.24 & 0.174 & 0.01 & 0.94 \\
\hline ERD (\%) & 78.8 & 78.3 & 75.6 & 76.0 & 1.49 & 0.03 & 0.65 \\
\hline \multicolumn{8}{|l|}{ Timothy hay } \\
\hline $\mathrm{a}(\%)$ & 19.7 & 18.9 & 19.7 & 19.0 & 0.37 & 0.38 & 0.92 \\
\hline b (\%) & 51.8 & 60.8 & 61.2 & 62.0 & 4.30 & 0.16 & 0.37 \\
\hline $\mathrm{c}(/ \mathrm{h})$ & 0.033 & 0.022 & 0.019 & 0.017 & 0.0041 & 0.01 & 0.20 \\
\hline Lag time $(\mathrm{h})$ & 4.47 & 1.66 & 2.42 & 1.65 & 0.841 & 0.08 & 0.26 \\
\hline $\operatorname{ERD}(\%)$ & 36.1 & 35.1 & 33.4 & 33.3 & 1.24 & 0.03 & 0.56 \\
\hline
\end{tabular}

${ }^{1} \mathrm{a}=$ soluble and rapidly degradable fraction; $\mathrm{b}=$ slowly degradable fraction; $\mathrm{c}=$ fractional rate of disappearance of the fraction $\mathrm{b}$; ERD = effective ruminal degradability.

ing time $(/ \mathrm{kg}$ of DMI or $/ \mathrm{kg}$ of $\mathrm{NDF})$ were reduced as DDGS was incorporated (20\% of dietary DM) in dairy cow diets in replacement of barley grain (Zhang et al., 2010).

\section{In Sacco Ruminal Degradability}

In sacco ruminal OM degradation parameters of flaked corn, soybean meal, and timothy hay are presented in Table 4. The soluble and rapidly degradable fraction (a), the slowly degradable fraction (b), the fractional rate of degradation (c), and the ERD of flaked corn were not affected $(P \geq 0.13)$ by increasing the proportion of DDGS in the diet and averaged $43 \%, 56 \%$, $0.059 / \mathrm{h}$, and $70 \%$, respectively. The lack of a change in ruminal degradability of flaked corn (i.e., source of starch) coupled with decrease in starch intake (Table 3) as DDGS proportion increased in the diet suggests a decline in the amount of starch escaping ruminal degradation. Reynolds (2006) reported that postruminal digestion of starch declined with increasing starch outflow from the rumen, which may explain the quadratic decrease in apparent total-tract digestibility of starch.

The soluble and rapidly degradable fraction of $\mathrm{OM}$ of soybean meal averaged $40.3 \%$, whereas the slowly degradable fraction averaged $59.6 \%$ and both were not significantly affected by DDGS treatment. A tendency $(P=0.08)$ was observed for a linear decrease in the fractional degradation rate of soybean meal, whereas the lag time decreased linearly $(P=0.01)$ as the proportion of DDGS increased in the diet. These changes caused a linear decline $(P=0.03)$ in soybean meal ERD by $0.5,3.2$, and 2.8 percentage units at DDGS 10, 20, and $30 \%$, respectively. The decline in ruminal degradability of soybean meal (Table 4) and the concomitant increase in apparent total-tract CP digestibility (Table 3 ) with increasing DDGS proportions in the diet indicate an increase in postruminal digestion of dietary $\mathrm{CP}$.

The response of timothy hay ruminal degradability kinetics to DDGS supplementation was similar to that of soybean meal. The soluble and rapidly degradable fraction and the slowly degradable fraction averaged 19 and $59 \%$ across treatments, respectively, and both were not affected $(P \geq 0.16)$ by DDGS addition. However, a linear decline $(P=0.01)$ in the fractional rate of degradation and a tendency $(P=0.09)$ for a linear decrease in the lag time were observed with increasing DDGS proportions in the diet. As a result, timothy hay ERD declined linearly $(P=0.03)$ by $1.0,2.7$, and 2.8 percentage units at DDGS 10,20 , and $30 \%$, respectively, suggesting that ruminal fibrolytic activity was reduced by the incorporation of DDGS in the diet. Islas and Soto-Navarro (2011) also reported a numerical decrease in NDF ruminal fractional degradation rate as DDGS proportion increased from 0 to $15 \%$ in the diet of grazing beef heifers. Leupp et al. (2009) observed a tendency for lower $\operatorname{NDF}(P=0.08)$ and $\operatorname{ADF}(P$ $=0.09$ ) ruminal degradabilities as the proportion of DDGS (replacing rolled corn, sunflower meal, and urea) increased (up to $60 \%$ of $\mathrm{DM}$ ) in the diet of growing steers, associated with a quadratic increase in duodenal flows of NDF and ADF. Higher EE content of DDGS 
diets compared with 0\% DDGS diet (Table 2) may explain the effect of treatment on ruminal NDF degradability. In sacco ruminal degradability of barley silage was negatively affected by addition of unprotected fat to the diet (Chung et al., 2011).

Postruminal digestion of NDF when cows were fed diets containing 10 and 20\% DDGS may have occurred and would be a possible explanation for the quadratic effect of DDGS on NDF apparent total-tract digestibility (Table 3). The decrease in ruminal degradability of hay is consistent with the decline observed in apparent total-tract NDF digestibility when cows were fed diets with $30 \%$ DDGS treatment (Table 3 ). The reduced apparent total-tract digestibility of NDF at the highest inclusion rate of DDGS could be also be explained by an increased ruminal passage rate (due to increased DMI) and a decline in digestion at postruminal sites. Data from Leupp et al. (2009) also suggest a shift in NDF digestion from the rumen to hind gut in steers fed up to $60 \%$ DDGS in the diet.

\section{Ruminal Fermentation Characteristics and Protozoa Counts}

Ruminal $\mathrm{pH}$, total VFA concentration, VFA molar proportions, $\mathrm{NH}_{3}$ concentration, and protozoa counts are presented in Table 5. Because the interactions between day and treatment were not significant for any of the variables reported, only averages of the 2-d measurements were reported. No treatment $\times$ time interaction was observed for any of the ruminal fermentation parameters measured except for acetate, propionate, and butyrate molar proportions. In the current study, despite cows being fed highly digestible diets and had high DMI levels, the mean daily ruminal $\mathrm{pH}$ remained relatively high (averaging 6.21) and was not affected
$(P \geq 0.40)$ by DDGS supplementation. The diets contained high concentrations of $\mathrm{NDF}(>32 \%)$, mostly from forage, and moderate concentrations of starch $(\leq 19 \%)$, which ensured adequate salivation and buffering capacity of the rumen fluid. Other studies fed diets with similar characteristics (i.e., forage:concentrate ratio and NDF concentration) at the same DMI level and reported similar rumen $\mathrm{pH}$ values (Yang and Beauchemin, 2007; Yang and Beauchemin, 2009).

A tendency $(P=0.06)$ was observed for a quadratic increase in minimum $\mathrm{pH}$ as dietary DDGS level increased in the diet. This could be related to a reduction in starch and increase in NDF concentrations as the proportion of dietary DDGS increased in the diet. $\mathrm{Ru}-$ minal degradation of NDF is much slower than starch, which causes less accumulation of VFA in the rumen and less ruminal $\mathrm{pH}$ fluctuation after feeding. No effect of feeding distillers grains on ruminal $\mathrm{pH}$ has been reported previously (Schingoethe et al., 1983; Zhang et al., 2010; Islas and Soto-Navarro, 2011).

Total VFA concentration decreased linearly $(P<$ $0.01)$ as the proportion of DDGS increased in the diet. Other studies also reported lower ruminal total VFA concentrations when DDGS were fed to dairy or beef cattle (Nichols et al., 1998; Kleinschmit et al., 2006; Leupp et al., 2009) compared with those fed control diets. In vitro incubation $(24 \mathrm{~h})$ of DDGS with ruminal fluid produced $28 \%$ less total VFA than that produced from incubating corn grain (Getachew et al., 2004), reflecting lower ruminal degradability of DDGS compared with corn grain. Reduction in total VFA concentration as DDGS proportion in the diet increased are consistent with the reduced ruminal degradability of $\mathrm{OM}$ of hay and soybean meal (Table 4) and the decline in apparent total-tract digestibility of DM, OM, and GE observed with DDGS diets (Table 3).

Table 5. Ruminal fermentation characteristics and protozoa counts of ruminal fluid of lactating cows fed diets supplemented with increasing amounts of corn dried distillers grains with solubles (DDGS)

\begin{tabular}{|c|c|c|c|c|c|c|c|}
\hline \multirow[b]{2}{*}{ Item } & \multicolumn{4}{|c|}{ DDGS } & \multirow[b]{2}{*}{ SEM } & \multicolumn{2}{|c|}{$P$-value } \\
\hline & $0 \%$ & $10 \%$ & $20 \%$ & $30 \%$ & & Linear & Quadratic \\
\hline \multicolumn{8}{|l|}{$\mathrm{pH}$} \\
\hline Mean & 6.21 & 6.21 & 6.27 & 6.22 & 0.058 & 0.40 & 0.42 \\
\hline Minimum & 5.92 & 5.92 & 5.98 & 5.97 & 0.055 & 0.95 & 0.06 \\
\hline Maximum & 6.56 & 6.59 & 6.64 & 6.55 & 0.068 & 0.16 & 0.54 \\
\hline Total VFA (mM) & 99.3 & 96.1 & 93.6 & 91.1 & 6.17 & $<0.01$ & 0.84 \\
\hline \multicolumn{8}{|l|}{ VFA $(\mathrm{mol} / 100 \mathrm{~mol})$} \\
\hline Acetate (A) & 63.4 & 62.7 & 61.8 & 60.1 & 0.83 & $<0.01$ & 0.07 \\
\hline Propionate $(\mathrm{P})$ & 21.8 & 22.1 & 22.3 & 23.1 & 0.81 & 0.01 & 0.53 \\
\hline Butyrate & 11.5 & 12.0 & 12.8 & 13.7 & 0.21 & $<0.01$ & 0.15 \\
\hline Isobutyrate & 0.83 & 0.76 & 0.74 & 0.70 & 0.029 & $<0.01$ & 0.25 \\
\hline Valerate & 1.17 & 1.21 & 1.22 & 1.30 & 0.038 & $<0.01$ & 0.17 \\
\hline Isovalerate & 1.36 & 1.22 & 1.17 & 1.10 & 0.060 & $<0.01$ & 0.23 \\
\hline $\mathrm{A}: \mathrm{P}$ & 3.01 & 2.91 & 2.83 & 2.67 & 0.133 & $<0.01$ & 0.56 \\
\hline $\mathrm{NH}_{3}(\mathrm{~m} M)$ & 8.38 & 7.51 & 6.68 & 6.06 & 0.307 & $<0.01$ & 0.71 \\
\hline Protozoa $\left(\times 10^{5} / \mathrm{mL}\right)$ & 5.12 & 5.28 & 5.42 & 4.48 & 0.46 & 0.15 & 0.04 \\
\hline
\end{tabular}


Treatment $\times$ sampling time interactions for molar proportions of acetate, propionate, and butyrate were due to changes in the magnitude of differences between treatments at each sampling time. Molar proportion of acetate decreased linearly $(P<0.01$; Figure 1$)$, whereas molar proportions of propionate (Figure 2 ) and butyrate (Figure 3) increased linearly $(P<0.01)$ as the DDGS proportion in the diet increased. The reduction in acetate molar proportion could be related to the decrease in ruminal fiber digestion, as illustrated by the observed decline in ruminal degradability of timothy hay (Table 4) as the DDGS proportion in the diet increased. The increase in propionate molar proportion as dietary proportion of DDGS increases is a consequence of a decline in acetate molar proportion rather than an increase in propionate concentration. Indeed, the concentration of propionate in ruminal fluid was not affected by DDGS addition and averaged $21.5 \mathrm{~m} M(P=0.71$; data not shown), which was consistent with the lack of an effect of DDGS on in sacco ruminal degradability of flaked corn (Table 4). With increasing dietary DDGS inclusion, Leupp et al. (2009) reported a decline in acetate molar proportion but an increase in that of propionate, with no effect on butyrate molar proportion in beef cattle. Anderson et al. (2006) reported a numerical decrease in acetate molar proportion and an increase in propionate and butyrate proportions in dairy cows fed DDGS diets. Others reported no effect of dietary DDGS inclusion on acetate or propionate molar proportions (Kleinschmit et al., 2006; Zhang et al., 2010). The decrease in acetate proportion as DDGS inclusion rate increased caused a linear decrease $(P<0.01)$ in acetate:propionate ratio (Table 5). Similar observations have been reported in some studies (Anderson et al., 2006; Leupp et al., 2009), but not others (Nichols et al., 1998; Kleinschmit et al., 2006). It is generally assumed that supplementation of fat to ruminant diets reduces the ruminal acetate:propionate ratio (Getachew et al., 2004; McGinn et al., 2004; Chung et al., 2011). Effect of DDGS on acetate:propionate ratio is, thus, related to the increase in EE intake as DDGS dietary proportion increased (Table 3).

The molar proportion of valerate increased linearly $(P<0.01)$, whereas the proportion of branched-chain VFA (isobutyrate and isovalerate) declined linearly $(P$ $<0.01)$ with increasing DDGS proportions in the diet (Table 5). Ruminal $\mathrm{NH}_{3}$ concentration also decreased linearly $(P<0.01)$ as the proportion of DDGS in the diet increased (Table 5). Similarly to our study, other studies (Nichols et al., 1998; Anderson et al., 2006; Kleinschmit et al., 2006) also reported reductions in ruminal $\mathrm{NH}_{3}$ concentration and branched-chain VFA molar proportions when DDGS replaced partially the concentrate portion of dairy cow diets. Decreases in

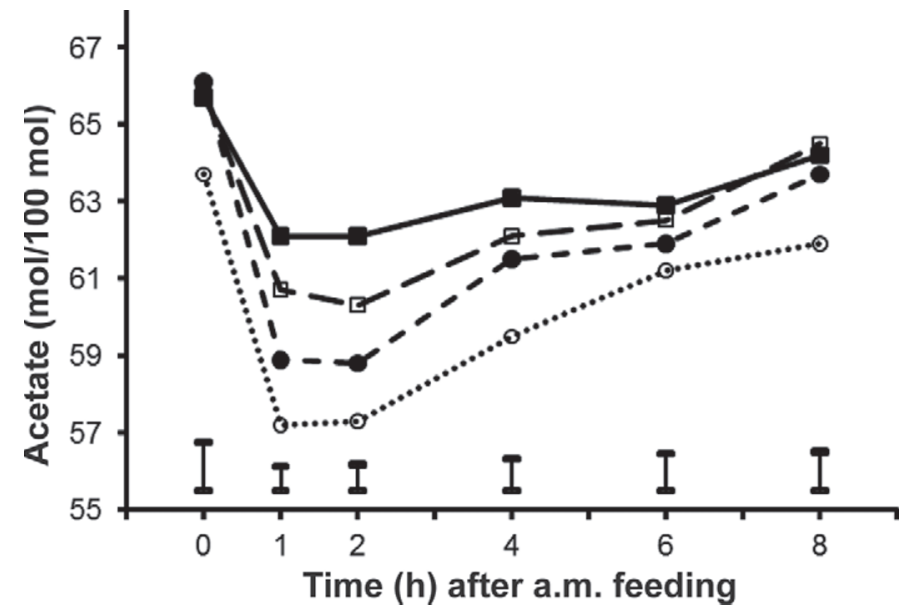

Figure 1. Ruminal acetate molar proportion in lactating cows fed diets supplemented with increasing amounts of corn dried distillers grains with solubles (DDGS; $\square \%, \square 10 \%, \bullet 20 \%, \bigcirc 30 \%$ ).

ruminal $\mathrm{NH}_{3}$ and branched-chain VFA are an indication of a reduction in ruminal degradation of protein, as illustrated by the decline in ERD of soybean meal observed in the current study for cows fed DDGS diets as compared with those fed the 0\% DDGS diet (Table 4).

Supplementation with DDGS caused a quadratic $(P$ $=0.04)$ response in protozoa count, being lowest at $30 \%$ DDGS (Table 5), which may be explained by the higher EE concentration (Table 2) and intake (Table 3 ) at this supplementation level. Incorporating fat in the diet of dairy cows has been reported to reduce protozoa numbers in ruminal fluid both in vitro and in vivo (Machmüller et al., 1998; Beauchemin et al., 2009; Chung et al., 2011). The reduction in total protozoa

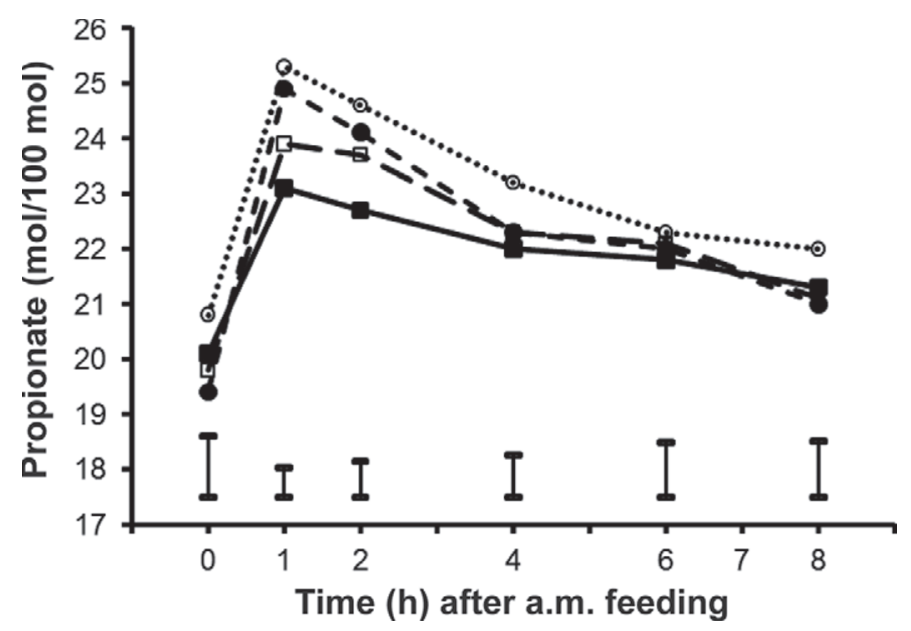

Figure 2. Ruminal propionate molar proportion in lactating cows fed diets supplemented with increasing amounts of corn dried distillers grains with solubles (DDGS; $0 \%, \square 10 \%, \bullet 20 \%, \bigcirc 30 \%$ ). 


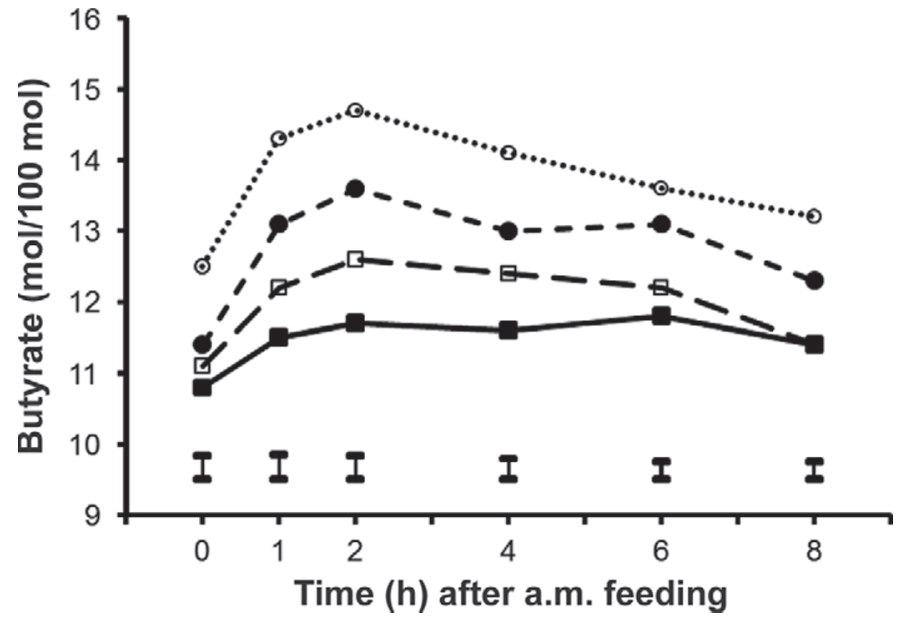

Figure 3. Ruminal butyrate molar proportion in lactating cows fed diets supplemented with increasing amounts of corn dried distillers grains with solubles (DDGS; $0 \%, \square 10 \%, \bullet 20 \%, \bigcirc 30 \%$ ).

count may also explain at least partially the decrease in $\mathrm{NH}_{3}$ concentration (Table 5) and the resulting reduction in in sacco ruminal degradation of soybean meal (Table 4). Reducing ruminal protozoa contributes to improving $\mathrm{N}$ efficiency by decreasing ruminal protein degradation and intraruminal $\mathrm{N}$ recycling, and increasing microbial $\mathrm{N}$ uptake and microbial protein synthesis (Ushida and Jouany, 1985; Williams and Coleman, 1988; Oldick and Firkins, 2000).

\section{Milk Production and Milk Composition}

Milk production increased linearly $(P<0.01)$ with increasing DDGS proportions in the diet. Cows offered the $30 \%$ DDGS diet produced $4 \mathrm{~kg} / \mathrm{d}$ more milk than when offered the diet with 0\% DDGS supplementation. This increase in milk yield is consistent with the higher DM and energy intakes of cows fed DDGS diets compared with cows fed the 0\% DDGS diet (Table 3).

Fat and protein percentages decreased linearly $(P$ $<0.01)$ with increasing DDGS inclusion in the diet, whereas a quadratic effect $(P<0.01)$ of DDGS addition on MUN concentration was observed. Milk urea nitrogen is an indicator of BUN, which is formed from $\mathrm{NH}_{3}$ absorbed from the rumen, or AA catabolism at the tissue level. Ruminal $\mathrm{NH}_{3}$ concentration declined linearly with the addition of DDGS in the diet, which explains the decline in MUN when DDGS were included up to $20 \%$ of the diet. The increase in MUN concentration at 30\% DDGS may be due to the increased supply of AA at the intestinal level and the eventual use of AA for gluconeogenesis, which might have increased AA deamination and the concentration of BUN. The decline in milk fat content can be related to the decrease in ruminal molar proportion of acetate
(Table 5). According to Bauman and Griinari (2001), diets causing a decrease in milk fat content and yield also alter ruminal lipid metabolism, resulting in the formation of specific biohydrogenation intermediates of the trans-10 pathway that directly inhibit milk fat synthesis. Such changes may explain the linear decrease in milk fat content observed in the current study. A tendency for a quadratic effect of DDGS on FCM $(P=$ $0.09)$ and $\operatorname{ECM}(P=0.10)$ yields was observed, as cows fed DDGS diets produced, on average, $2 \mathrm{~kg} / \mathrm{d}$ more FCM or ECM than cows fed the 0\% DDGS diet. Fat yield was not significantly $(P>0.05)$ changed by experimental treatment, although it tended $(P=0.08)$ to respond quadratically to increasing inclusion of DDGS in the diet. Protein $(P=0.03)$ and lactose $(P<0.01)$ yields increased linearly when cows were fed increasing proportions of DDGS, indicating no negative effect of increasing EE intake in the diet (via DDGS addition) on production parameters.

A similar positive effect of DDGS on dairy cow performance has been reported previously (Anderson et al., 2006; Kleinschmit et al., 2006; Janicek et al., 2008). According to a review by Schingoethe et al. (2009), adding corn distillers grains with solubles to dairy cattle diets either improved or had no effect on milk production parameters. Milk yield of high-producing dairy cows in early to mid lactation responded positively to incorporating corn distillers grains in their diets, but not in low-producing, late-lactation cows (Janicek et al., 2008; Hollmann et al., 2011), which supports our findings. The observed increase in milk yield reported in this study was also noted by Janicek et al. (2008) but not by Kleinschmit et al. (2006) and Anderson et al. (2006). In the last 2 studies, the higher milk production was, in fact, due to the greater energy density of the diets containing corn distillers grains.

Reported effects of DDGS on milk fat concentration have been variable among studies. For instance, and similarly to our findings, Leonardi et al. (2005) observed no change in milk fat yield when the proportion of DDGS increased (from 0 to $15 \%$, DM basis) in the diet; however, milk fat concentration decreased linearly due to increased milk production in that study. In the same study, the authors observed a reduction in the proportions of short-chain FA coupled with an increase in the proportions of long-chain FA in milk, suggesting that de novo FA synthesis in the mammary gland was inhibited, but this was offset by uptake and increased secretion of long-chain FA, more likely absorbed from the diet (Leonardi et al., 2005). Other studies (Kleinschmit et al., 2006; Janicek et al., 2008) reported no changes in milk fat content when cows were fed DDGS diets. In a meta-analysis study, Hollmann et al. (2011) reported that the negative effect of corn 
distillers grains on milk fat concentration occurs more likely when milk fat concentration of cows fed control treatments is greater than $3.6 \%$, which is in agreement with findings of the present study. The same study also reported that FCM yield increased by up to $2.2 \mathrm{~kg} / \mathrm{cow}$ per day when $20 \%$ DDGS were incorporated in the diet, compared with the 0\% DDGS diet, which also agrees with our findings.

In the current study, the higher milk protein yield observed as dietary DDGS proportion increased in the diet may be explained by a greater supply of AA due to (1) an increased feed $\mathrm{N}$ intake coupled with an increase in CP digestibility and (or) (2) a reduction in protein degradation in the rumen as reflected by declines in ruminal $\mathrm{NH}_{3}$ concentration, branched-chain VFA molar proportions, protozoa numbers (Table 5), and the ERD of soybean meal (Table 4). Gehman and Kononoff (2010) observed enhanced microbial protein synthesis when cows were fed $25 \%$ corn wet distillers grains (replacing corn silage or alfalfa silage, corn, soybean meal, and heat-treated soybean), which may further explain the greater protein secretion in milk observed in the current study. Higher intestinal availability and higher arterial concentrations of essential and nonessential AA were reported when cows were fed diet containing corn distillers grains compared with a control diet containing soybean meal (Nichols et al., 1998; Mjoun et al., 2010).

Feed efficiency (expressed as kilogram of ECM produced per kilogram of DMI) averaged 1.51 and was not affected $(P>0.19)$ by increasing the level of DDGS in the diet. In contrast, Anderson et al. (2006) and Kleinschmit et al. (2006) reported higher feed efficiency when cows were fed diets containing $20 \%$ of wet or dry corn distillers grains with solubles. In those 2 studies, DMI was not changed (Kleinschmit et al., 2006) or tended to decrease (Anderson et al., 2006), whereas milk yield increased in cows fed corn distillers grains with solubles, explaining the improved feed efficiency compared with our findings. On the other hand, weight gain $(\mathrm{kg} / \mathrm{d})$ increased linearly $(P<0.01)$ when cows were fed 10,20, and 30\% DDGS diets by 21, 162, and $227 \%$ compared with 0\% DDGS (Table 6). Thus, cows also displayed higher productivity when DDGS diets were fed.

\section{Methane Production}

No interactions were observed between day and treatment for $\mathrm{CH}_{4}$ measurements and, therefore, only averages over the 3 -d measurements were reported (Table 7). Methane production was $495 \mathrm{~g} / \mathrm{d}$ for cows consuming 0\% DDGS diet and declined linearly $(P=$ $0.03)$ as DDGS proportion in the diet increased. When expressed on DMI basis, $\mathrm{CH}_{4}$ production declined lin- early $(P<0.01)$ by 2,4 , and $8 \%$ at DDGS proportion 10,20 , and $30 \%$, respectively. This indicates that, on average, a $1 \%$ increase in fat decreased $\mathrm{CH}_{4}$ production by $0.5 \mathrm{~g} / \mathrm{kg}$ of DMI $(0.5,0.4$, and 0.7 for 10,20 , and $30 \%$ DDGS, respectively). The model $\left[\mathrm{CH}_{4}(\mathrm{~g} / \mathrm{kg}\right.$ of DMI) $=24.55( \pm 1.029)-0.102( \pm 0.0147)$ dietary fat $(\mathrm{g} / \mathrm{kg})$; diets containing $<80 \mathrm{~g}$ of fat $/ \mathrm{kg}$ of $\mathrm{DM}$ ] of Grainger and Beauchemin (2011) predicted a $1 \mathrm{~g}$ of $\mathrm{CH}_{4} / \mathrm{kg}$ of DMI decrease for each $1 \%$ increase in dietary fat. This may suggest that the proposed model does not allow accurate predictions of enteric $\mathrm{CH}_{4}$ emission changes under a wide range of dietary lipid-supplementation conditions (e.g., DDGS supplementation).

Methane energy losses as a percentage of GE intake decreased linearly $(P<0.01)$ by 5,8 , and $14 \%$ in cows fed 10, 20, and 30\% DDGS diets, respectively, compared with cows fed the 0\% DDGS diet. Similarly, when corrected for digestible energy intake, $\mathrm{CH}_{4}$ decreased linearly $(P<0.01)$ as the amount of DDGS in the diet increased. When expressed on a milk-yield basis ( $\mathrm{g}$ of $\mathrm{CH}_{4} / \mathrm{kg}$ of milk), $\mathrm{CH}_{4}$ production declined linearly by 9,13 , and $15 \%$ for 10, 20, and 30\% DDGS diets, respectively. Similarly, the amount of $\mathrm{CH}_{4}$ produced per kilogram of FCM $(P=0.04)$ or ECM $(P=0.02)$ decreased linearly by an average of $9 \%$ in cows fed increasing proportions of DDGS in the diet. A quadratic effect $(P=0.05)$ of DDGS on $\mathrm{CH}_{4}$ production was observed, related to kilograms of milk fat produced. When expressed on the basis of kilograms of milk protein produced, $\mathrm{CH}_{4}$ production declined linearly $(P<$ 0.01 ) as the DDGS proportion increased in the diet.

Studies on the effect of DDGS on $\mathrm{CH}_{4}$ production in cattle are scarce. Using the head box technique, Birkelo et al. (2004) reported a $14 \%$ decline in $\mathrm{CH}_{4}$ energy losses (\% of GE intake) when cows were fed $31 \%$ wet corn distillers grains, which is similar to the extent of decrease observed in the present study. In that study, the lower $\mathrm{CH}_{4}$ production was associated with a decrease in DMI. More recently, McGinn et al. (2009) used the sulfur hexafluoride $\left(\mathrm{SF}_{6}\right)$ tracer technique and observed a $24 \%$ decrease in $\mathrm{CH}_{4}$ production (\% of GE intake) with no concomitant effect on DMI when DDGS (35\% of dietary DM) replaced barley grain in growing beef cattle diets.

The observed decline in $\mathrm{CH}_{4}$ production could be attributed mainly to the high EE content in DDGS diets compared with the 0\% DDGS diet (Table 2). Feeding 10, 20, and 30\% DDGS diets increased total EE intake by 30,61 , and $95 \%$ compared with $0 \%$ DDGS diet (Table 3). Several studies have reported decreases in enteric $\mathrm{CH}_{4}$ emissions when cattle diets were supplemented with unprotected fat (Beauchemin et al., 2009; Grainger et al., 2010; Chung et al., 2011). The negative effect of increasing dietary EE intake on 
Table 6. Milk production, milk composition, BW, and BW gain of lactating cows fed diets supplemented with increasing amounts of corn dried distillers grains with solubles (DDGS)

\begin{tabular}{|c|c|c|c|c|c|c|c|}
\hline \multirow[b]{2}{*}{ Item } & \multicolumn{4}{|c|}{ DDGS } & \multirow[b]{2}{*}{ SEM } & \multicolumn{2}{|c|}{$P$-value } \\
\hline & $0 \%$ & $10 \%$ & $20 \%$ & $30 \%$ & & Linear & Quadratic \\
\hline \multicolumn{8}{|l|}{ Production $(\mathrm{kg} / \mathrm{d})$} \\
\hline Milk & 32.6 & 35.1 & 35.8 & 36.6 & 1.97 & $<0.01$ & 0.22 \\
\hline $4 \% \mathrm{FCM}^{1}$ & 32.1 & 34.5 & 34.1 & 33.7 & 2.16 & 0.22 & 0.09 \\
\hline $\mathrm{ECM}^{2}$ & 35.3 & 37.8 & 37.3 & 37.1 & 2.20 & 0.16 & 0.10 \\
\hline \multicolumn{8}{|l|}{ Composition (\%) } \\
\hline Fat & 3.93 & 3.91 & 3.69 & 3.47 & 0.184 & $<0.01$ & 0.17 \\
\hline Protein & 3.49 & 3.41 & 3.31 & 3.31 & 0.047 & $<0.01$ & 0.31 \\
\hline Lactose & 4.60 & 4.63 & 4.59 & 4.58 & 0.027 & 0.42 & 0.26 \\
\hline $\mathrm{SCC}\left(\times 10^{3} / \mathrm{mL}\right)$ & 75 & 82 & 133 & 89 & 12.6 & 0.23 & 0.19 \\
\hline MUN $(\mathrm{mg} / \mathrm{dL})$ & 11.1 & 10.0 & 9.9 & 10.6 & 0.52 & 0.23 & $\leq 0.01$ \\
\hline \multicolumn{8}{|l|}{ Yield $(\mathrm{kg} / \mathrm{d})$} \\
\hline Fat & 1.27 & 1.36 & 1.32 & 1.27 & 0.099 & 0.80 & 0.08 \\
\hline Protein & 1.13 & 1.19 & 1.18 & 1.20 & 0.057 & 0.03 & 0.36 \\
\hline Lactose & 1.50 & 1.62 & 1.65 & 1.68 & 0.096 & $<0.01$ & 0.17 \\
\hline \multicolumn{8}{|l|}{ Feed efficiency } \\
\hline Milk/DMI & 1.40 & 1.44 & 1.44 & 1.45 & 0.056 & 0.23 & 0.51 \\
\hline $\mathrm{FCM} / \mathrm{DMI}$ & 1.37 & 1.42 & 1.37 & 1.33 & 0.068 & 0.20 & 0.17 \\
\hline $\mathrm{ECM} / \mathrm{DMI}$ & 1.51 & 1.55 & 1.50 & 1.46 & 0.067 & 0.19 & 0.23 \\
\hline \multicolumn{8}{|l|}{$\mathrm{BW}$} \\
\hline Initial (kg) & 700 & 701 & 697 & 698 & 15.8 & 0.41 & 0.87 \\
\hline Final $(\mathrm{kg})$ & 710 & 714 & 724 & 730 & 16.2 & $<0.01$ & 0.74 \\
\hline Gain (kg/d) & 0.29 & 0.35 & 0.76 & 0.95 & 0.150 & $<0.01$ & 0.43 \\
\hline
\end{tabular}

protozoa population (Table 5) may partially explain the observed reduction in $\mathrm{CH}_{4}$ production. Methanogens are present on and have a symbiotic relationship with protozoa. Hydrogen produced by protozoa during feed fermentation in the rumen is utilized by methanogens to produce $\mathrm{CH}_{4}$. Substantial methanogenic activity in the rumen has been linked to protozoa related methanogens (Vogels et al., 1980; Finlay et al., 1994; Newbold et al., 1995). Furthermore, EE from DDGS could have a toxic effect on other methanogens in the rumen, as observed with EE from linseed and soybean (Martin et al., 2008; Yang et al., 2009). The observed decline in the acetate:propionate ratio (Table 5) supports the speculation of a change in microbial population in the rumen toward less acetate-producing bacteria and less methanogenesis.

Reduction in ruminal fiber degradation may have also contributed to reduced $\mathrm{CH}_{4}$ production. Decreases in timothy hay in sacco ruminal degradability (Table 4) and the acetate molar proportion (Table 5) as DDGS

Table 7. Methane production of lactating cows fed diets supplemented with increasing amounts of corn dried distillers grains with solubles (DDGS)

\begin{tabular}{|c|c|c|c|c|c|c|c|}
\hline \multirow[b]{2}{*}{ Item } & \multicolumn{4}{|c|}{ DDGS } & \multirow[b]{2}{*}{ SEM } & \multicolumn{2}{|c|}{$P$-value } \\
\hline & $0 \%$ & $10 \%$ & $20 \%$ & $30 \%$ & & Linear & Quadratic \\
\hline $\begin{array}{l}\mathrm{DMI},{ }^{1} \mathrm{~kg} / \mathrm{d} \\
\mathrm{CH}\end{array}$ & 24.2 & 24.6 & 24.4 & 25.3 & 0.80 & 0.10 & 0.55 \\
\hline $\mathrm{g} / \mathrm{d}^{1}$ & 495 & 490 & 477 & 475 & 21.0 & 0.03 & 0.84 \\
\hline $\mathrm{g} / \mathrm{kg}$ of $\mathrm{DMI}^{1}$ & 20.6 & 20.1 & 19.7 & 18.9 & 0.62 & $<0.01$ & 0.43 \\
\hline$\%$ of GE intake ${ }^{1}$ & 6.09 & 5.80 & 5.61 & 5.23 & 0.173 & $<0.01$ & 0.56 \\
\hline$\%$ of DE intake ${ }^{2}$ & 8.75 & 8.39 & 8.17 & 7.74 & 0.241 & $<0.01$ & 0.79 \\
\hline $\mathrm{g} / \mathrm{kg}$ of milk ${ }^{3}$ & 15.6 & 14.2 & 13.6 & 13.2 & 0.60 & $<0.01$ & 0.18 \\
\hline $\mathrm{g} / \mathrm{kg}$ of $\mathrm{FCM}^{3}$ & 15.7 & 14.3 & 14.3 & 14.4 & 0.53 & 0.04 & 0.07 \\
\hline $\mathrm{g} / \mathrm{kg}$ of $\mathrm{ECM}^{3}$ & 14.3 & 13.1 & 13.0 & 13.0 & 0.47 & 0.02 & 0.09 \\
\hline $\mathrm{g} / \mathrm{kg}$ of milk fat ${ }^{3}$ & 396 & 363 & 372 & 390 & 19.1 & 0.87 & 0.05 \\
\hline $\mathrm{g} / \mathrm{kg}$ of milk protein ${ }^{3}$ & 446 & 415 & 411 & 400 & 15.5 & $<0.01$ & 0.29 \\
\hline
\end{tabular}

${ }^{1}$ Determined for 3 consecutive days during which cows were in the chambers.

${ }^{2} \mathrm{DE}=$ digestible energy (estimated from energy digestibility measured over the 7-d collection period).

${ }^{3}$ Yields of milk, FCM, ECM, milk fat, and milk protein measured for 7 consecutive days (i.e., performance measurements). 
proportion in the diet increased support this assumption. Ruminal degradation of fiber is known to promote acetate production in the rumen, which liberates hydrogen that is used by methanogens to form $\mathrm{CH}_{4}$ (Van Soest, 1994). This can be also related to the higher EE concentrations in DDGS diets.

Several studies reported a decline in total-tract NDF digestibility coupled with a decrease in $\mathrm{CH}_{4}$ emissions when unprotected fat was added to ruminant diets (Martin et al., 2008; Beauchemin et al., 2009; Chung et al., 2011), which agrees with what is observed for $30 \%$ DDGS treatment in the current study. In agreement with our observations, Leupp et al. (2009) reported tendencies for quadratic effects on ruminal digestion $(P=0.08)$ and apparent total-tract digestibility $(P=$ $0.13)$ of NDF in steers fed up to $60 \%$ DDGS in the diet. Contrarily, Birkelo et al. (2004) reported an increase in apparent total-tract digestibility when cows were fed diets containing $31 \%$ wet corn distillers grains. Discrepancies could be related to the amount of distillers grains included in the diet and, hence, the amount of EE added to the dietary DM. In the present study, the $0 \%$ DDGS diet contained $4 \% \mathrm{EE}$, which increased up to $7.2 \%$ in the $30 \%$ DDGS diet (Table 2). In the Birkelo et al. (2004) study, the total EE concentration of the control and the distillers grain diet were 3.1 and $5.1 \%$, respectively. Thus, the amount of EE ingested by cows in the experiment of Birkelo et al. (2004) may not have been sufficient to negatively affect NDF digestion. In a meta-analysis, Eugène et al. (2008) showed that increasing the lipid content of the diet decreased enteric $\mathrm{CH}_{4}$ production and linked this decrease to a decline in DMI. However, the reduction in $\mathrm{CH}_{4}$ production observed in the current study was not associated with a decrease in DMI (Table 3), suggesting that changes in ruminal methanogenesis was a result of disturbances of rumen fermentation caused by supplemental EE (i.e., DDGS).

\section{N Balance}

Daily $\mathrm{N}$ intake increased linearly $(P<0.01)$ with increasing DDGS proportion in the diet, which led to linear increases $(\mathrm{g} / \mathrm{d})$ of $\mathrm{N}$ output in feces $(P=0.05)$, urine $(P<0.01)$, N secretion in milk $(P=0.03)$, and body $\mathrm{N}$ retention (Table 8$)$. The higher DMI and the slightly higher dietary $\mathrm{N}$ content when cows were fed DDGS diets (Table 3) led to the increase in $\mathrm{N}$ intake. When expressed as a proportion of $\mathrm{N}$ intake, fecal $\mathrm{N}$ excretion declined linearly $(P=0.03)$, whereas urinary $\mathrm{N}$ output remained unaffected $(P \geq 0.35)$ by the dietary addition of increasing levels of DDGS. Total N excretion expressed as a percentage of $\mathrm{N}$ intake tended $(P=0.07)$ to decrease with increasing DDGS propor- tions in the diet. Efficiency of $\mathrm{N}$ use ( $\mathrm{g}$ of $\mathrm{N}$ used for milk protein synthesis and building body reserve/g of $\mathrm{N}$ intake) tended $(P=0.07)$ to increase with increasing DDGS proportions in the diet. Retained $\mathrm{N}$ as a proportion of $\mathrm{N}$ intake increased (up to +3.6 percentage units at $30 \%$ DDGS), whereas the proportion of $\mathrm{N}$ secreted in milk slightly declined (up to -1.7 percentage units at $30 \%$ DDGS) as dietary DDGS proportion increased. Assuming that the body tissue contains about $20 \%$ protein (NRC, 2001), the retention of $60 \mathrm{~g}$ of N/d (i.e., $375 \mathrm{~g}$ of protein/d) should have resulted in a BW gain of $1.85 \mathrm{~kg} / \mathrm{d}$. Considering the inherent errors associated (e.g., volatile $\mathrm{N}$ losses from urine and feces during collection) with $\mathrm{N}$ balance studies (MacRae et al., 1993; Spanghero and Kowalski, 1997), true N retention was likely overestimated, as illustrated by the modest BW change recorded (Table 2). Several studies also reported overestimation of $\mathrm{N}$ retention during $\mathrm{N}$ balance determination trials (Ruppert et al., 2003; Benchaar et al., 2007; Colombini et al., 2012).

Very few studies have investigated in detail the effects of including corn distillers grains with solubles in dairy cow diets on $\mathrm{N}$ outputs and whole-body $\mathrm{N}$ partitioning. In one study (Gehman and Kononoff, 2010), feeding corn wet distillers grains to dairy cows increased $\mathrm{N}$ secretion in milk, $\mathrm{N}$ retention, and efficiency of $\mathrm{N}$ utilization for productive uses, which agrees with our findings.

\section{CONCLUSIONS}

Enteric $\mathrm{CH}_{4}$ production (g/d) was reduced when increasing proportions of DDGS were incorporated in the diet of dairy cows at the expense of corn and soybean meal. Intake of DM and milk yield responded positively to increasing DDGS proportions in the diet. Thus, when expressed as a percentage of $\mathrm{GE}$ intake, $\mathrm{CH}_{4}$ production was decreased by up to $14 \%$ at the highest inclusion rate (i.e., $30 \%$ of dietary DM) of DDGS. Similar extents of decrease were also noted when $\mathrm{CH}_{4}$ production was corrected for digestible energy intake (up to $12 \%$ at $30 \%$ DDGS supplementation). When related to FCM or ECM yield, $\mathrm{CH}_{4}$ production $(\mathrm{g} / \mathrm{kg}$ of FCM or ECM) declined linearly with increasing DDGS proportions in the diet. Increasing the EE supply as DDGS proportion in the diet increased and its effects on ruminal fiber degradation, acetate:propionate ratio, and protozoa numbers is considered the main reason for the reduction in $\mathrm{CH}_{4}$ production. Thus, inclusion of DDGS in the diet of dairy cows has the potential to reduce enteric $\mathrm{CH}_{4}$ production. Although the efficiency of $\mathrm{N}$ utilization (i.e., higher retained $\mathrm{N}$ and productive $\mathrm{N})$ was improved by the addition of DDGS in the diet, the resulting greater $\mathrm{N}$ excretion in the manure needs 
Table 8. Nitrogen balance in lactating cows fed diets supplemented with increasing amounts of corn distillers grains with solubles (DDGS)

\begin{tabular}{|c|c|c|c|c|c|c|c|}
\hline \multirow[b]{2}{*}{ Item } & \multicolumn{4}{|c|}{ DDGS } & \multirow[b]{2}{*}{ SEM } & \multicolumn{2}{|c|}{$P$-value } \\
\hline & $0 \%$ & $10 \%$ & $20 \%$ & $30 \%$ & & Linear & Quadratic \\
\hline Intake $\mathrm{N}, \mathrm{g} / \mathrm{d}$ & 606 & 642 & 655 & 682 & 17.5 & $<0.01$ & 0.71 \\
\hline \multicolumn{8}{|l|}{ Fecal N } \\
\hline $\mathrm{g} / \mathrm{d}$ & 198 & 204 & 207 & 211 & 7.2 & 0.05 & 0.89 \\
\hline$\%$ of $\mathrm{N}$ intake & 32.7 & 31.7 & 31.6 & 30.8 & 0.70 & 0.03 & 0.80 \\
\hline \multicolumn{8}{|l|}{ Urinary N } \\
\hline $\mathrm{g} / \mathrm{d}$ & 204 & 209 & 213 & 223 & 8.6 & $<0.01$ & 0.59 \\
\hline$\%$ of $\mathrm{N}$ intake & 33.7 & 32.7 & 32.7 & 32.6 & 1.28 & 0.35 & 0.51 \\
\hline \multicolumn{8}{|l|}{ Total N excretion } \\
\hline $\mathrm{g} / \mathrm{d}$ & 402 & 413 & 419 & 434 & 13.0 & $<0.01$ & 0.81 \\
\hline$\%$ of $\mathrm{N}$ intake & 66.4 & 64.4 & 64.3 & 63.5 & 1.47 & 0.07 & 0.56 \\
\hline \multicolumn{8}{|l|}{ Milk N } \\
\hline $\mathrm{g} / \mathrm{d}$ & 177 & 187 & 185 & 189 & 8.9 & 0.03 & 0.36 \\
\hline$\%$ of $\mathrm{N}$ intake & 29.4 & 29.1 & 28.2 & 27.7 & 1.02 & $<0.01$ & 0.83 \\
\hline \multicolumn{8}{|l|}{ Retained N } \\
\hline $\mathrm{g} / \mathrm{d}$ & 33 & 42 & 51 & 60 & 9.9 & 0.05 & 0.99 \\
\hline$\%$ of $\mathrm{N}$ intake & 5.29 & 6.53 & 7.58 & 8.85 & 1.51 & 0.08 & 0.99 \\
\hline \multicolumn{8}{|l|}{ Productive $\mathrm{N}^{1}$} \\
\hline $\mathrm{g} / \mathrm{d}$ & 204 & 229 & 236 & 248 & 12.3 & $<0.01$ & 0.53 \\
\hline$\%$ of $\mathrm{N}$ intake & 34.6 & 35.6 & 35.7 & 36.5 & 1.47 & 0.07 & 0.56 \\
\hline
\end{tabular}

${ }^{1}$ Retained $\mathrm{N}+$ milk N.

to be taken into account for better assessment of the overall environmental impact of feeding DDGS to dairy cows.

\section{ACKNOWLEDGMENTS}

The authors thank the Dairy and Swine Research Centre (Agriculture and Agri-Food Canada, Sherbrooke, QC, Canada) staff, including L. Croteau and P. Warburton (technical support), F. Tremblay (methane measurements), S. Méthot (help with the statistical analyses), and the barn crew (care of the cows). The authors also express their thanks to Y. Leboeuf and M. Gingras (Université Laval, Quebec, QC, Canada) for their technical support. C. Julien was a visiting scientist from UMR INRA-INPT ENSAT-INPT ENVT (Castanet Tolosan, France). The donation of DDGS by GreenField Ethanol Inc. (Varennes, QC, Canada) was much appreciated. This study was funded by a grant (Dairy Research Cluster) from Agriculture and AgriFood Canada (Ottawa, ON, Canada), Dairy Farmers of Canada (Ottawa, ON, Canada), and the Canadian Dairy Commission (Ottawa, ON, Canada).

\section{REFERENCES}

Anderson, J. L., D. J. Schingoethe, K. F. Kalscheur, and A. R. Hippen. 2006. Evaluation of dried and wet distillers grains included at two concentrations in the diets of lactating dairy cows. J. Dairy Sci. 89:3133-3142.

AOAC (Association of Official Analytical Chemists). 1990. Official Methods of Analysis. 15th ed. AOAC, Arlington, VA.

Bauman, D. E., and J. M. Griinari. 2001. Regulation and nutritional manipulation of milk fat: Low-fat milk syndrome. Livest. Prod. Sci. $70: 15-29$
Beauchemin, K. A., S. M. McGinn, C. Benchaar, and L. Holtshausen. 2009. Crushed sunflower, flax, or canola seeds in lactating dairy cow diets: Effects on methane production, rumen fermentation, and milk production. J. Dairy Sci. 92:2118-2127.

Beauchemin, K. A, S. M. McGinn, and H. V. Petit. 2007. Methane abatement strategies for cattle: Lipid supplementation of diets. Can. J. Anim. Sci. 87:431-440.

Benchaar, C., H. V. Petit, R. Berthiaume, D. R. Ouellet, J. Chiquette, and P. Y. Chouinard. 2007. Effects of essential oils on digestion, ruminal fermentation, rumen microbial populations, milk production, and milk composition in dairy cows fed alfalfa silage or corn silage. J. Dairy Sci. 90:886-897.

Birkelo, C. P., M. J. Brouk, and D. J. Schingoethe. 2004. The energy content of wet corn distillers grains for lactating dairy cows. J. Dairy Sci. 87:1815-1819.

CCAC (Canadian Council on Animal Care). 1993. Guide to the Care and Use of Experimental Animals. Vol. 1. 2nd ed. CCAC, Ottawa, ON, Canada.

Chung, Y. H., M. L. He, S. M. McGinn, T. A. McAllister, and K. A. Beauchemin. 2011. Linseed suppresses enteric methane emissions from cattle fed barley silage, but not from those fed grass hay. Anim. Feed Sci. Technol. 166-167:321-329.

Colombini, S., G. Galassi, G. M. Crovetto, and L. Rapetti. 2012. Milk production, nitrogen balance, and fiber digestibility prediction of corn, whole plant grain sorghum, and forage sorghum silages in the dairy cow. J. Dairy Sci. 95:4457-4467.

EPA (Environmental Protection Agency). 2006. Global anthropogenic non- $\mathrm{CO}_{2}$ greenhouse gas emissions: 1990-2020. US EPA, ed. US EPA, Washington, DC.

Eugène, M., D. Massé, J. Chiquette, and C. Benchaar. 2008. Metaanalysis on the effects of lipid supplementation on methane production in lactating dairy cows. Can. J. Anim. Sci. 88:331-337.

FAO (Food and Agriculture Organization of the United Nations). 2006. Livestock's long shadow. Environmental issues and options. Accessed July 13, 2012. http://www.fao.org/docrep/010/a0701e/ a0701e00.htm.

Finlay, B. J., G. Esteban, K. J. Clarke, A. G. Williams, T. M. Embley, and R. P. Hirt. 1994. Some rumen ciliates have endosymbiotic methanogens. FEMS Microbiol. Lett. 117:157-161.

Gehman, A. M., and P. J. Kononoff. 2010. Utilization of nitrogen in cows consuming wet distillers grains with solubles in alfalfa and corn silage-based dairy rations. J. Dairy Sci. 93:3166-3175. 
Getachew, G., P. H. Robinson, E. J. DePeters, and S. J. Taylor. 2004. Relationships between chemical composition, dry matter degradation and in vitro gas production of several ruminant feeds. Anim. Feed Sci. Technol. 111:57-71.

Grainger, C., and K. A. Beauchemin. 2011. Can enteric methane emissions from ruminants be lowered without lowering their production? Anim. Feed Sci. Technol. 166-167:308-320.

Grainger, C., R. Williams, T. Clarke, A. D. G. Wright, and R. J. Eckard. 2010. Supplementation with whole cottonseed causes longterm reduction of methane emissions from lactating dairy cows offered a forage and cereal grain diet. J. Dairy Sci. 93:2612-2619.

Hall, M. B., J. P. Jennings, B. A. Lewis, and J. B. Robertson. 2001. Evaluation of starch analysis methods for feed samples. J. Sci. Food Agric. 81:17-21.

Hollmann, M., M. S. Allen, and D. K. Beede. 2011. Diet fermentability influences lactational performance responses to corn distillers grains: A meta-analysis. J. Dairy Sci. 94:2007-2021.

Islas, A., and S. A. Soto-Navarro. 2011. Effect of supplementation of dried distillers grains with solubles on forage intake and characteristics of digestion of beef heifers grazing small-grain pasture. J. Anim. Sci. 89:1229-1237.

Janicek, B. N., P. J. Kononoff, A. M. Gehman, and P. H. Doane. 2008 The effect of feeding dried distillers grains plus solubles on milk production and excretion of urinary purine derivatives. J. Dairy Sci. 91:3544-3553.

Kleinschmit, D. H., J. L. Anderson, D. J. Schingoethe, K. F. Kalscheur, and A. R. Hippen. 2007. Ruminal and intestinal degradability of distillers grains plus solubles varies by source. J. Dairy Sci. 90:2909-2918.

Kleinschmit, D. H., D. J. Schingoethe, K. F. Kalscheur, and A. R Hippen. 2006. Evaluation of various sources of corn dried distillers grains plus solubles for lactating dairy cattle. J. Dairy Sci. 89:4784-4794.

Leonardi, C., S. Bertics, and L. E. Armentano. 2005. Effect of increasing oil from distillers grains or corn oil on lactation performance. J. Dairy Sci. 88:2820-2827.

Leupp, J. L., G. P. Lardy, K. K. Karges, M. L. Gibson, and J. S. Caton. 2009. Effects of increasing level of corn distillers dried grains with solubles on intake, digestion, and ruminal fermentation in steers fed seventy percent concentrate diets. J. Anim. Sci. 87:2906-2912.

Machmüller, A., D. A. Ossowski, M. Wanner, and M. Kreuzer. 1998. Potential of various fatty feeds to reduce methane release from rumen fermentation in vitro (Rusitec). Anim. Feed Sci. Technol. 71:117-130.

MacRae, J. C., A. Walker, D. Brown, and G. E. Lobley. 1993. Accretion of total protein and individual amino acids by organs and tissues of growing lambs and the ability of nitrogen balance techniques to quantitate protein retention. Anim. Prod. 57:237-245.

Martin, C., J. Rouel, J. P. Jouany, M. Doreau, and Y. Chilliard. 2008. Methane output and diet digestibility in response to feeding dairy cows crude linseed, extruded linseed, or linseed oil. J. Anim. Sci. $86: 2642-2650$.

McDonald, I. 1981. A revised model for the estimation of protein degradability in the rumen. J. Agric. Sci. 96:251-252.

McGinn, S. M., K. A. Beauchemin, T. Coates, and D. Colombatto. 2004. Methane emissions from beef cattle: Effects of monensin, sunflower oil, enzymes, yeast, and fumaric acid. J. Anim. Sci. 82:3346-3356.

McGinn, S. M., Y. H. Chung, K. A. Beauchemin, A. D. Iwaasa, and C. Grainger. 2009. Use of corn distillers dried grains to reduce enteric methane loss from beef cattle. Can. J. Anim. Sci. 89:409-413.

Mjoun, K., K. F. Kalscheur, A. R. Hippen, and D. J. Schingoethe. 2010. Ruminal degradability and intestinal digestibility of protein and amino acids in soybean and corn distillers grains products. J. Dairy Sci. 93:4144-4154.

Newbold, C. J., B. Lassalas, and J. P. Jouany. 1995. The importance of methanogens associated with ciliate protozoa in ruminal methane production in vitro. Lett. Appl. Microbiol. 21:230-234.

Nichols, J. R., D. J. Schingoethe, H. A. Maiga, M. J. Brouk, and M. S. Piepenbrink. 1998. Evaluation of corn distillers grains and ru- minally protected lysine and methionine for lactating dairy cows. J. Dairy Sci. 81:482-491.

NRC. 2001. Nutrient Requirements of Dairy Cattle. 7th rev. ed. NRC Academy Press, Washington, DC.

Ogimoto, K., and S. Imai. 1981. Techniques in rumen microbiology. Page 158 in Atlas of Rumen Microbiology. Japan Scientific Societies Press, Tokyo, Japan.

Oldick, B. S., and J. L. Firkins. 2000. Effects of degree of fat saturation on fiber digestion and microbial protein synthesis when diets are fed twelve times daily. J. Anim. Sci. 78:2412-2420.

Penner, G. B., P. Yu, and D. A. Christensen. 2009. Effect of replacing forage or concentrate with wet or dry distillers' grains on the productivity and chewing activity of dairy cattle. Anim. Feed Sci. Technol. 153:1-10.

Ranathunga, S. D., K. F. Kalscheur, A. R. Hippen, and D. J. Schingoethe. 2010. Replacement of starch from corn with nonforage fiber from distillers grains and soyhulls in diets of lactating dairy cows. J. Dairy Sci. 93:1086-1097.

Reynolds, C. K. 2006. Production and metabolic effects of site of starch digestion in dairy cattle. Anim. Feed Sci. Technol. 130:78-94.

Robinson, P. H., K. Karges, and M. L. Gibson. 2008. Nutritional evaluation of four co-product feedstuffs from the motor fuel ethanol distillation industry in the Midwestern USA. Anim. Feed Sci. Technol. 146:345-352.

Ruppert, L. D., J. K. Drackley, D. R. Bremmer, and J. H. Clark. 2003. Effects of tallow in diets based on corn silage or alfalfa silage on digestion and nutrient use by lactating dairy cows. J. Dairy Sci. $86: 593-609$.

Schingoethe, D. J., A. K. Clark, and H. H. Voelker. 1983. Wet corn distillers grains in lactating dairy cow rations. J. Dairy Sci. $66: 345-349$.

Schingoethe, D. J., K. F. Kalscheur, A. R. Hippen, and A. D. Garcia. 2009. Invited review: The use of distillers products in dairy cattle diets. J. Dairy Sci. 92:5802-5813.

Spanghero, M., and Z. M. Kowalski. 1997. Critical analysis of N balance experiments with lactating cows. Livest. Prod. Sci. 52:113122

Tedeschi, L. O., P. J. Kononoff, K. Karges, and M. L. Gibson. 2009. Effects of chemical composition variation on the dynamics of ruminal fermentation and biological value of corn milling (co)products. J. Dairy Sci. 92:401-413.

Ushida, K., and J.-P. Jouany. 1985. Effect of protozoa on rumen protein degradation in sheep. Reprod. Nutr. Dev. 25:1075-1081.

Van Soest, P. J. 1994. Nutritional Ecology of the Ruminant. Comstock Pub., Ithaca, NY

Van Soest, P. J., J. B. Robertson, and B. A. Lewis. 1991. Methods for dietary fiber, neutral detergent fiber, and nonstarch polysaccharides in relation to animal nutrition. J. Dairy Sci. 74:3583-3597.

Vogels, G. D., W. F. Hoppe, and C. K. Stumm. 1980. Association of methanogenic bacteria with rumen ciliates. Appl. Environ. Microbiol. 40:608-612.

Weatherburn, M. W. 1967. Phenol-hypochlorite reaction for determination of ammonia. Anal. Chem. 39:971-974.

Williams, A. G., and G. S. Coleman. 1988. The rumen protozoa. Pages 77-128 in The Rumen Microbial Ecosystem P. N. Hobson, ed. Elsevier Science Pub. Co., New York, NY.

Yang, S. L., D. P. Bu, J. Q. Wang, Z. Y. Hu, D. Li, H. Y. Wei, L. Y. Zhou, and J. J. Loor. 2009. Soybean oil and linseed oil supplementation affect profiles of ruminal microorganisms in dairy cows. Animal 3:1562-1569.

Yang, W. Z., and K. A. Beauchemin. 2007. Altering physically effective fiber intake through forage proportion and particle length: Chewing and ruminal pH. J. Dairy Sci. 90:2826-2838.

Yang, W. Z., and K. A. Beauchemin. 2009. Increasing physically effective fiber content of dairy cow diets through forage proportion versus forage chop length: Chewing and ruminal pH. J. Dairy Sci. 92:1603-1615.

Zhang, S. Z., G. B. Penner, W. Z. Yang, and M. Oba. 2010. Effects of partially replacing barley silage or barley grain with dried distillers grains with solubles on rumen fermentation and milk production of lactating dairy cows. J. Dairy Sci. 93:3231-3242. 